\title{
ANALISIS TEKNOEKONOMI PENGEMBANGAN MINERAL TEMBAGA DI INDONESIA
}

\author{
Techno-Economic Analysis of Copper Mineral Development in \\ Indonesia
}

\author{
IJANG SUHERMAN \\ Puslitbang Teknologi Mineral dan Batubara \\ Jalan Jenderal Sudirman 623, Bandung 40211 \\ Telp. 022 6030483, Fax. 0226003373 \\ e-mail: ijang@tekmira.esdm.go.id
}

\begin{abstract}
ABSTRAK
UU No 4 Tahun 2009 tentang Pertambangan Mineral dan Batubara, mewajibkan Kontrak Karya dan Pemegang IUP tembaga untuk melakukan peningkatan nilai tambah melalui pengolahan dan pemurnian di dalam negeri. Kegiatan pengolahan dan pemurnian dapat dilakukan sendiri atau bekerjasama dengan pihak lain. Untuk mendukung implementasi kebijakan tersebut, perlu analisis teknoekonomi pengembangan mineral tembaga di Indonesia. Tujuan dari analisis teknoekonomi ini adalah untuk mengetahui karakteristik pasar, nilai tambah dan strategi pengembangan mineral tembaga di Indonesia pada tataran global. Metode penelitian melalui cara survai dan analisis studio, menggunakan pendekatan statistika deskriptif, analisis trend, perhitungan nilai tambah dan analisis SWOT. Perkembangan produksi tembaga baik PT Freeport Indonesia maupun PT Newmont Nusa Tenggara cenderung menurun, hingga tahun 2014 total mencapai 1,684 juta ton. Dari jumlah tersebut 54,73\% oleh PT Smelting Gresik diolah dan dimurnikan menjadi katoda tembaga sebanyak 246 ribu ton per tahun. Sekitar $42,97 \%$ produk tersebut diserap di dalam negeri. Gambaran dari pasar produk tembaga dan olahannya baik di dalam negeri maupun secara global cukup positif mendukung pengembangan smelter tembaga di Indonesia. Adapun nilai tambah smelter tembaga sekitar 1,74 kali lipat dari nilai bahan baku (konsentrat tembaga). Untuk mendorong bergulirnya program roadmap pembangunan smelter tembaga di dalam negeri, dibutuhkan kebijakan antara lain regulasi Domestic Market Obligation (DMO) Hulu dan DMO Hilir serta pembangunan infrastruktur antara lain pembangkit listrik.
\end{abstract}

Kata kunci : teknoekonomi, kebijakan, pasar, nilai tambah, smelter tembaga.

\begin{abstract}
Referring to the Law No. 4 of 2009 on Mineral and Coal Mining, oblige CoW and IUP copper in order to increase the added value through processing and refining of minerals in the country. Processing and refining activities can be carried out alone or in cooperation with other parties. In order to support the implementation of the policy toward increasing the added value of copper mineral in the country, it is necessary to technoeconomic analysis on Development of copper in Indonesia. The purpose of this techno-aconomic analysis is to determine the characterization of the market, added value and development strategies of copper mineral in Indonesia at the world level. Methodology applied in this techno-analysis is based on survey and analysis studio, using descriptive statistics, trend analysis, calculation added value and SWOT analysis. In principle, the result of the techno-analysis could be briefly clarified that the development production of copper for both the PT Freeport Indonesia and PT Newmont Nusa Tenggara trends to decrease, until the year 2014 totaled 1.684 million tons. Of these, $54,73 \%$ by PT Smelting Gresik processed and refined into copper cathodes about 246 thousand tons per year. Approximately 42,97\% of these products are absorbed domestically. Market overview of copper and processed products both domestically and globally is quite positive to support the development of copper smelter in Indonesia. The added value of copper smelters around 1.74 times compared to raw materials (copper concentrate). Crash program to encourage the development roadmap
\end{abstract}


copper smelter in the country, required policies include regulations Domestic Market Obligation (DMO) Upstream and Downstream DMO and infrastructure development such as power plants.

Keywords: teckno-economic, policy, market, added value, copper smelter.

\section{PENDAHULUAN}

Bijih Tembaga merupakan sumber daya alam yang tidak terbaharukan (non renewable) yang dikuasai negara, dan harus dipergunakan sebesarbesarnya untuk kemakmuran rakyat. Oleh karenanya, pengelolaannya harus memberi nilai tambah bagi perekonomian nasional guna mencapai kemakmuran dan kesejahteraan rakyat, sebagaimana amanat pasal 33 UUD 1945.

Dua perusahaan Kontrak Karya (KK) skala internasional, yaitu PT Freeport Indonesia (PT FI) di Provinsi Papua dan PT Newmont Nusa Tenggara (PT NNT) di Provinsi Nusa Tenggara Barat, saat ini mengusahakan penambangan dan pengolahan bijih tembaga menjadi konsentrat tembaga sebesar 1.953.209 ton per tahun. Sekitar $30 \%$ konsentrat tersebut diolah dan dimurnikan oleh PT Smelting di Gresik dan sebagian lagi (70\%) diekspor ke luar negeri, antara lain ke Jepang. Produk utama PT smelting tersebut adalah katoda tembaga, sekitar $45 \%$ diserap di pasar dalam negeri dan sebagiannya lagi diekspor. Produk sampingnya berupa asam sulfat diserap oleh PT Petrokimia sebagai bahan baku pupuk, produk samping berupa gipsum dan terak tembaga (copper slag) diserap oleh pabrik semen, sedangkan produk samping lumpur anoda (anoda slime) yang mengandung emas, perak, dan mineral ikutan lainnya yang bernilai ekonomi diekspor ke luar negeri untuk dimurnikan lebih lanjut.

Dengan adanya UU No 4 Tahun 2009 tentang Pertambangan Mineral dan Batubara mewajibkan KK dan Pemegang IUP untuk melakukan peningkatan nilai tambah mineral melalui pengolahan dan pemurnian di dalam negeri. Kegiatan pengolahan dan pemurnian dapat dilakukan sendiri atau bekerjasama dengan pihak lain. Melalui kebijakan peningkatan nilai tambah, Indonesia tidak lagi sekedar menjual bahan tambang mentah yang mengakibatkan terjadinya deplesi dan pengurasan terhadap sumberdaya mineral, namun akan memiliki mata rantai yang panjang dengan masingmasing tahap proses merupakan proses peningkatan nilai tambah (Islah, 2009 dan Yunianto, 2014).
PT FI berencana untuk meningkatkan kapasitas smelter domestik sehingga seluruh produksi konsentrat tembaga dapat dimurnikan di dalam negeri. Lokasi pembangunan smelter tersebut bersebelahan dengan PT Smelting. Di samping itu, Pemerintah Daerah Papua akan membangun fasilitas pemurnian dengan kapasitas 900 ribu ton/tahun konsentrat tembaga. Adapun PT NNT akan bekerjasama dengan pihak lain untuk membangun fasilitas pemurnian di dalam negeri (DJMB, 2015).

Dalam rangka mendukung implementasi kebijakan peningkatan nilai tambah tembaga di dalam negeri, maka tujuan dari analisis penelitian ini adalah :

- melakukan analisis pasar produk berbasis tembaga;

- melakukan analisis nilai tambah smelter tembaga;

- melakukan analisis pengembangan smelter;

- merumuskan strategi pengembangan smelter di dalam negeri.

\section{METODE}

Metode yang digunakan dalam kegiatan ini adalah metode penelitian survai (survey research) pada perusahaan tambang tembaga yang sudah beroperasi, yaitu PT FI di Grasberg-Tembagapura, Kabupaten Mimika, Provinsi Papua dan PT NNT di Batu Hijau, Kabupaten Sumbawa Barat, Provinsi Nusa Tenggara Barat, serta industri pengolahan tembaga PT Smelting di Gresik, Provinsi Jawa Timur. Di samping itu, digunakan metoda penelitian nonsurvei, yaitu dilakukan di studio yang meliputi penelusuran referensi, pengolahan dan analisis. Pengumpulan data menggunakan teknik observasi dan wawancara berpanduan (interview guide), sedangkan model pengolahan dan teknik analisis, digunakan pendekatan statistika deskriptif, model analisis trend, nilai tambah dan analisis SWOT.

\section{Statistika Deskriptif}

Statistika deskriptif adalah metoda statistika yang digunakan untuk analisis data dengan 
cara mendeskripsikan atau menggambarkan data yang telah terkumpul sebagaimana adanya tanpa ada tujuan membuat kesimpulan untuk generalisasi. Informasi yang dapat diperoleh dari statistika deskriptif ini antara lain ukuran pemusatan data, ukuran penyebaran data dan kecenderungan suatu gugus data yang disajikan dalam grafik atau tabel.

\section{Analisis Trend}

Analisis trend merupakan suatu metode analisis statistika yang ditujukan untuk melakukan pemodelan data berkala dan digunakan untuk suatu estimasi atau peramalan pada masa yang akan datang. Beberapa model yang dapat digunakan untuk analisis trend atau sering disebut time series ini adalah

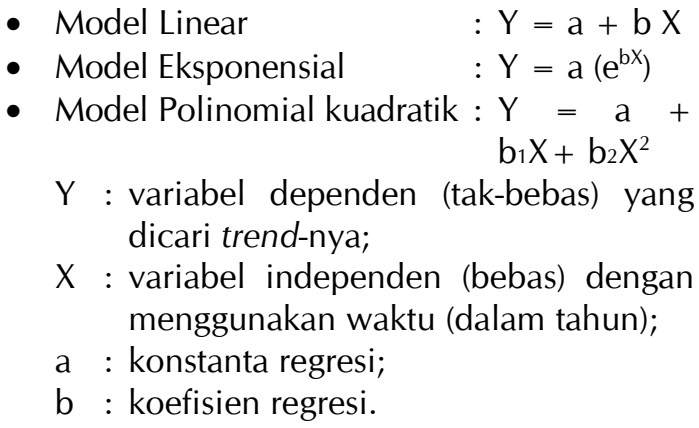

Untuk memudahkan pengolahan dan analisis data, digunakan Program Excell atau Program Statistical Package for the Social Sciences (SPSS).

\section{Model Perhitungan Nilai Tambah}

Peningkatan nilai tambah didefinisikan sebagai suatu proses pengolahan hasil tambang (baik yang dilakukan satu tahap maupun beberapa tahap) yang bertujuan untuk menghasilkan suatu produk atau komoditi sehing-ga nilai ekonomi dan daya gunanya meningkat lebih tinggi dari sebelumnya, serta aktivitas yang ditimbulkan akan memberikan dampak positif terhadap perekonomian dan sosial baik bagi daerah operasional, pusat, maupun daerah non operasional.

Salah satu teori ekonomi untuk menghitung nilai tambah mineral ini adalah "pendekatan pendapatan". Dalam pendekatan pendapatan ini, nilai tambah dari setiap kegiatan ekonomi dihitung dengan jalan menjumlahkan semua balas jasa faktor produksi yaitu upah dan gaji, surplus usaha, penyusutan dan pajak tidak langsung neto. Untuk sektor pemerintahan dan usaha-usaha yang sifatnya tidak mencari untung, surplus usaha tidak diperhitungkan. Yang termasuk dalam surplus usaha adalah bunga, sewa tanah dan keuntungan.

\section{Analisis SWOT}

Analisis SWOT adalah analisis faktor-faktor internal maupun eksternal yang selanjutnya akan digunakan sebagai dasar untuk merancang strategi dan program kerja. Analisis internal meliputi penilaian terhadap faktor kekuatan (Strengths) dan kelemahan (Weaknesses). Sementara, analisis eksternal mencakup faktor peluang (Opportuniies) dan tantangan (Threats).

Pendekatan kualitatif matriks SWOT sebagaimana dikembangkan oleh Kearns menampilkan delapan kotak, yaitu dua paling atas adalah kotak faktor internal (Kekuatan dan Kelemahan) sedangkan dua kotak sebelah kiri adalah kotak faktor eksternal (Peluang dan Tantangan). Empat kotak lainnya merupakan kotak isu-isu strategis yang timbul sebagai hasil titik pertemuan antara faktor-faktor internal dan eksternal (Tabel 1).

\section{HASIL DAN PEMBAHASAN}

\section{Ketersediaan Potensi Bijih Tembaga}

Berdasarkan data dari Pusat Sumber Daya Geologi, potensi tambang tembaga hampir tersebar di seluruh Indonesia yaitu di Sumatera (Tangse, Muarasipongi, Pagar Gunung, Sulit Air, Sumpahan, Lubuk Selasih, S.Tubun), di Jawa (G.Gede, Kasihan, G.Domasan, dan Noyu-Ngrandon), di Kalimantan (Barol dan Ruwai), di Sulawesi (Bulagidun, Selatan Buol, Tapadaa, Sungai Mak, Tulabalo, Matamboto, Kayubulan, Tambulitato, S. Manupu, Sasak, Sangkaropi) dan di Irian Jaya (Komopa dan Dawagu), di Mataram (Batuhijau dan Taemaman) dan sekitar Ternate (Kaputusan) (Gambar 1). Hingga tahun 2012, telah diidentifikasi jumlah sumberdaya tembaga adalah 17,464 miliar ton bijih dan 105,806 juta ton logam. Adapun dari jumlah cadangan adalah 3,045 miliar ton bijih dan 27,183 juta ton logam. Potensi sumberdaya terbesar terdapat di Provinsi Nusa Tenggara Barat serta di Provinsi Papua. Hingga saat ini, penambangan bijih tembaga dilakukan oleh dua perusahaan besar 
yaitu PT FI dan PT NNT.

PT FI mengusahakan penambangan bijih tembaga di Grasberg, Papua yang termasuk salah satu tambang emas terbesar di dunia dan terbesar ketiga untuk tambang tembaga. Hingga akhir tahun 2014, tercatat mempunyai cadangan 2,269 miliar ton dengan kadar: $1,02 \% \mathrm{Cu}, \quad 0,83 \mathrm{gram} / \mathrm{ton}$ emas and 4,32 gram/ton perak (PT Freeport Indonesia, 2015).
PT NNT mengusahakan penambangan tembaga dan emas di Batu Hijau, Sumbawa Barat. Konstruksi dan pembangunan infrastruktur selesai pada tahun 1999, dan mulai beroperasi tahun 2000. Hingga akhir tahun 2014, tercatat mempunyai cadangan 709,008 juta ton dengan kadar: 0,432\% Cu, 0,341 gram/ton emas and 1,103 gram/ton perak (PT Newmont Nusa Tenggara, 2015).

Tabel 1. Matrik hubungan faktor internal dengan eksternal

\begin{tabular}{|c|c|c|}
\hline \multirow{2}{*}{ Faktor Eksternal } & \multicolumn{2}{|c|}{ Faktor Internal } \\
\hline & Strengths (S) & Weaknesses (W) \\
\hline Opportunities (O) & $\begin{array}{l}\text { Strategi SO: } \\
\text { mengembangkan suatu strategi dalam } \\
\text { memanfaatkan kekuatan }(\mathrm{S}) \text { untuk mengambil } \\
\text { manfaat dari peluang }(\mathrm{O}) \text { yang ada. }\end{array}$ & $\begin{array}{l}\text { Strategi WO: } \\
\text { mengembangkan suatu strategi dalam } \\
\text { memanfaatkan peluang }(\mathrm{O}) \text { untuk } \\
\text { mengatasi kelemahan }(\mathrm{W}) \text { yang ada. }\end{array}$ \\
\hline Threats (T) & $\begin{array}{l}\text { Strategi ST: } \\
\text { mengembangkan suatu strategi dalam } \\
\text { memanfaatkan kekuatan }(\mathrm{S}) \text { untuk } \\
\text { menghindari ancaman }(\mathrm{T}) \text {. }\end{array}$ & $\begin{array}{l}\text { Strategi WT: } \\
\text { mengembangkan suatu strategi dalam } \\
\text { mengurangi kelemahan }(\mathrm{W}) \text { dan } \\
\text { menghindari ancaman }(\mathrm{T}) \text {. } \\
\end{array}$ \\
\hline
\end{tabular}

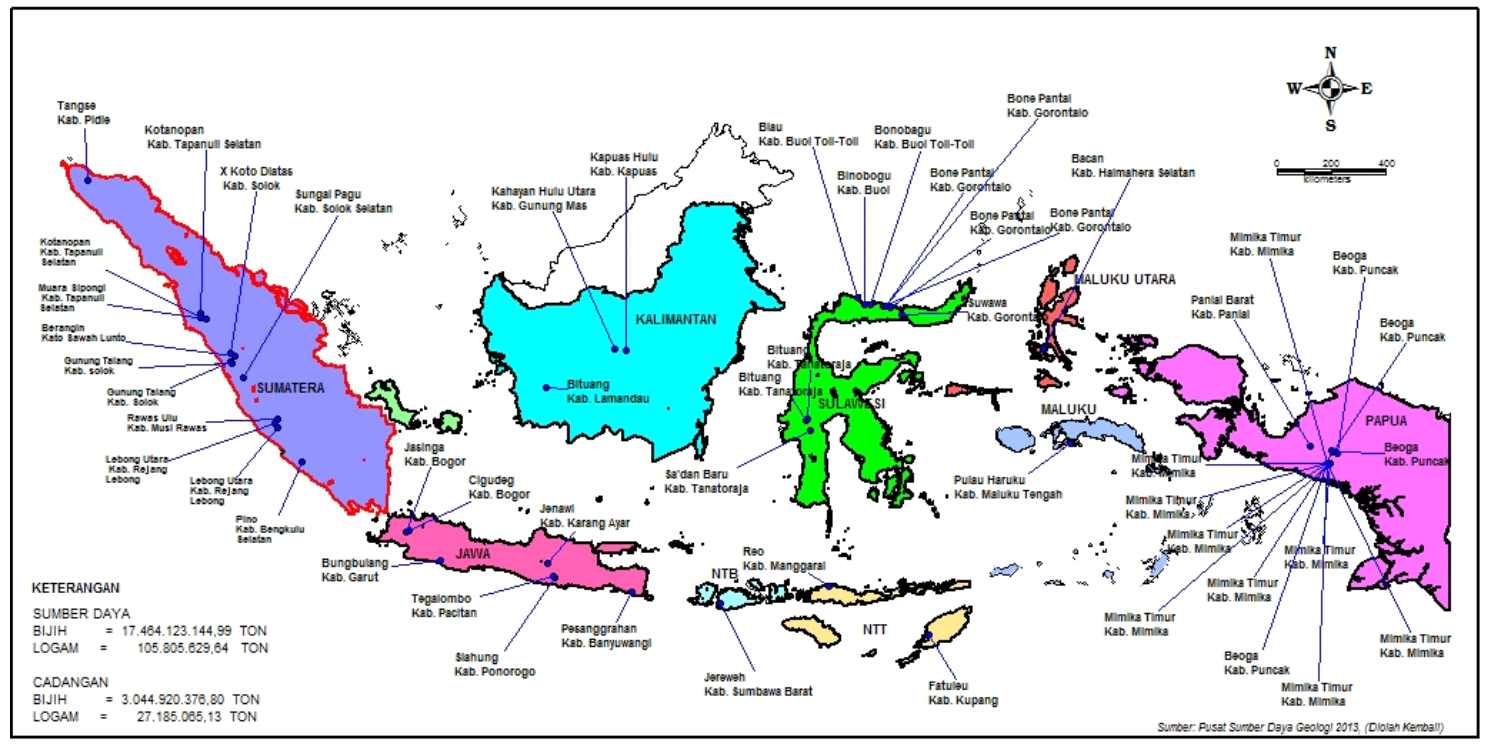

Sumber : Pusat Sumber Daya Geologi, 2013, diolah kembali

Gambar 1. Sebaran sumbedaya dan cadangan tembaga di Indonesia, tahun 2012 


\section{Analisis Pasar}

\section{Perkembangan Pasar Tembaga Dunia}

Berdasarkan data tingkat produksi tembaga tahun 2014 dari International Copper Study Group (ICSG), peranan Indonesia di pasar dunia sekitar 2,1\% (produksi dunia mencapai 18,7 juta ton) (Gambar 2a), atau menduduki peringkat ke 13 turun dari peringkat ke 5 selama empat tahun terakhir. Padahal berdasarkan kapasitas produksi, PT FI (790 ribu ton) menduduki peringkat ke 2 di bawah perusahaan dari Chili, sedangkan PT NNT (250 ribu ton) menduduki peringkat ke 15 . Di samping itu, trend produksi dunia menunjukkan peningkatan secara eksponensial dengan persamaan $y=4 \mathrm{E}-20 \mathrm{e}^{0,027 \mathrm{x}}$ dan koefisien determinasi $R^{2}=0,982$ (Gambar 2b). Pada tahun yang sama, produk smelter tembaga dunia didominasi oleh China sekitar 1,650 juta ton, Jepang 1,528 juta ton, serta India dan Republik Korea masing-masing sebesar 880 dan 640 ribu ton. Sedangkan negara lainnya mempunyai kapasitas produksi di bawah 450 ribu ton, salah satunya adalah Indonesia yang diwakili oleh PT Smelting-Gresik, dengan kapasitas 300 ribu ton tembaga. Seperti pola produksi tambang tembaga, dalam kurun waktu 54 tahun (1960-2014), diketahui trend refineri dan penggunaan tembaga dunia tumbuh secara eksponensial dengan persamaan y $=4 \mathrm{E}-18 \mathrm{e}^{0,024 \mathrm{x}}$, dan $\mathrm{y}=3 \mathrm{E}-18 \mathrm{e}^{0,025 \mathrm{x}}$, dengan koefisien determinasi masing masing $\mathrm{R}^{2}=$ 0,979 dan $R^{2}=0,976$.

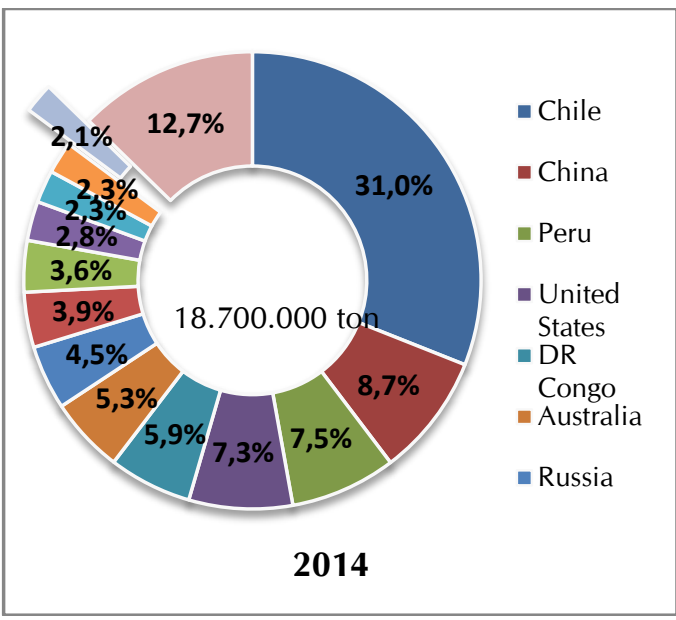

Sumber : ICSG, 2015 (diolah kembali)

Gambar 2a. Distribusti produksi tembaga dunia, tahun 2014

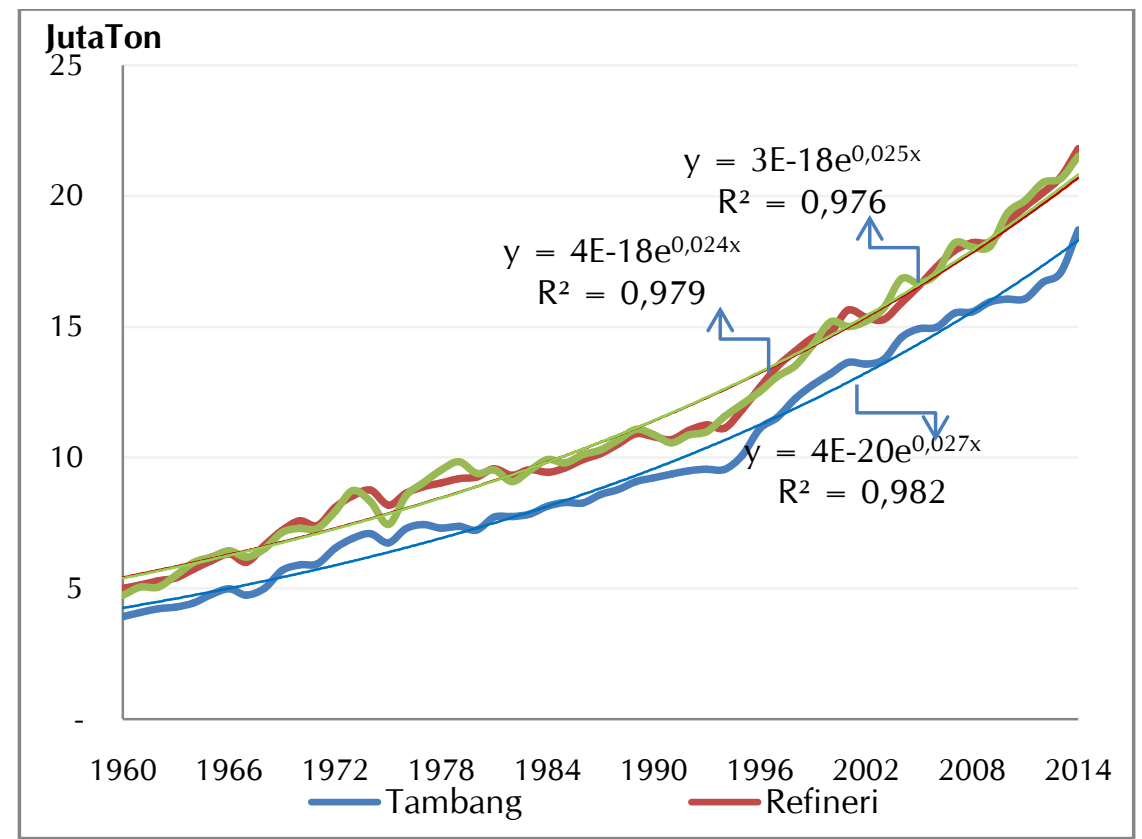

Sumber : ICSG, 2015 (diolah kembali)

Gambar 2b. Perkembangan produksi tambang dan refineri, serta penggunaan tembaga dunia, tahun 1960 - 2014 


\section{Perkembangan Pasar Tembaga Indonesia}

\section{Produksi dan Penjualan Konsentrat}

Tembaga merupakan salah satu sumberdaya mineral terpenting yang dimiliki Indonesia. Dua perusahaan besar skala internasional, yaitu PT FI dan PT NNT mengusahakan penambangan dan pengolahan bijih tembaga menjadi konsentrat tembaga, dengan mineral ikutan emas dan perak. Pertambangan PT FI berlokasi di Grasberg-Tembagapura, Kabupaten Mimika Provinsi Papua, sedangkan PT NNT berlokasi di Batu Hijau, Kabupaten Sumbawa Besar Provinsi Nusa Tenggara Barat. Sebelum tahun 2000, produksi konsentrat tembaga di Indonesia hanya berasal dari PT FI dan baru mulai tahun 2000, komoditi tersebut juga diproduksi oleh PT NNT.
Dalam perjalanan waktu 2000-2014, produksi konsentrat tembaga PT FI berfluktuasi dan cenderung menurun, dengan persamaan regresi polinomial $y=-7.565 x^{2}+2 E^{+08 x}+$ $3 \mathrm{E}^{+10}$ dan koefisien determinasi $\mathrm{R}^{2}=0,511$. Produksi yang meningkat pada tahun 2002, 2005, dan 2009, dengan puncak tertinggi pada tahun 2002 sebesar 2,835 juta ton. Sedangkan produksi yang menurun pada tahun 2004, 2008, dan pada 2014 yang terendah, yaitu sebesar 1,394 juta ton (Gambar 3a). Di sisi lain, dalam kecenderungan penurunan produksi, pasokan ke PT Smelting Gresik lebih diutamakan dibanding pasokan orientasi ekspor, sehingga persentasenya meningkat menjadi 58\%. (Gambar $3 b)$.

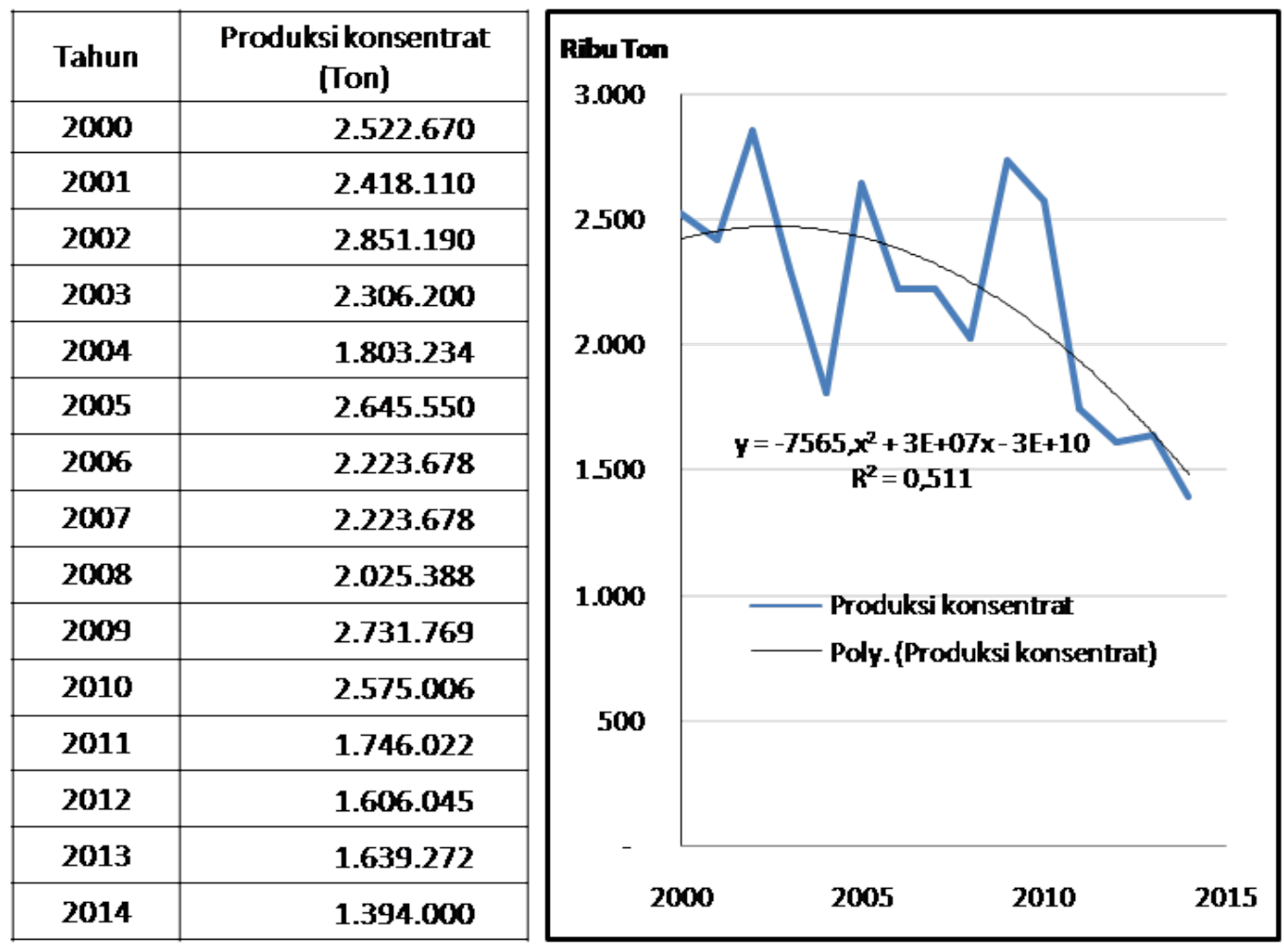

Sumber : DJMB dan PT Freeport Indonesia, 2015 (diolah kembali)

Gambar 3a. Perkembangan produksi konsentrat tembaga PT Freeport Indonesia, Tahun $2000-2014$ 


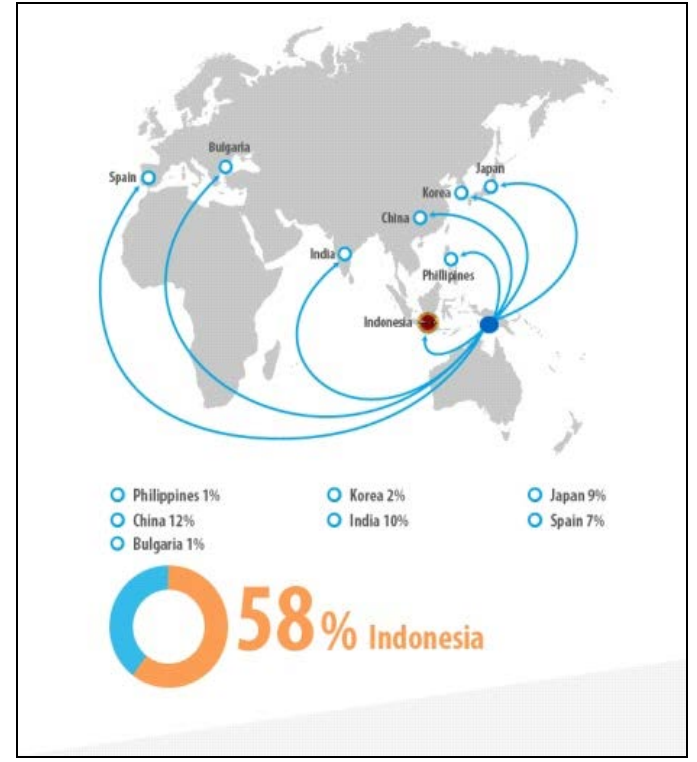

Sumber : PT Freeport Indonesia, 2015

Gambar 3b. Penjualan konsentrat tembaga PT Freeport Indonesia, Tahun 2014

PT NNT merupakan perusahaan patungan yang sahamnya dimiliki oleh Nusa Tenggara Partnership B.V, PT Multi Daerah Bersaing (PTMDB), PT Pukuafu Indah dan PT Indonesia Masbaga Investama. Newmont dan Sumitomo bertindak sebagai operator penambangan. Konstruksi dan pembangunan infrastruktur selesai pada tahun 1999, dan mulai beroperasi tahun 2000. Pada periode 2000-2014 perkembangan produksi PT NNT berfluktuasi dan cenderung menurun, dengan persamaan re-gresi polinomial $y=-$ $5.244 \mathrm{x}^{2}+2 \mathrm{E}^{+07 \mathrm{x}}-2 \mathrm{E}^{+10}$ dan koefisien determinasi $R^{2}=0,801$. Jumlah produksi yang menaik pada tahun 2004, 2007 dan 2010, dengan puncak tertinggi pada tahun 2002 sebesar 1.007,1 ribu ton. Sedangkan produksi yang menurun pada tahun 2006, 2008 dan yang terendah pada tahun 2014 sebesar 309,263 ribu ton (Gambar 4a). Penjualan pada tahun 2014 terbesar di dalam negeri sebesar $39 \%$, sedangkan ekspor ke Jepang sekitar 32\%, Korea 22\%, dan China 7\% (Gambar 4b).

Produksi konsentrat tembaga Indonesia merupakan share dari PT FI dan PT NNT, selain dipasok ke PT Smelting Gresik sekitar 921.669 ton $(54,73 \%)$ juga di ekspor ke luar negeri sekitar 762.457 ton $(45,27 \%)$ dengan pasar ter- besar adalah Jepang (28\%), kemudian diikuti oleh China (23\%), India (17\%), Spanyol (16\%), Korea Selatan (12\%), Bulgaria $(2 \%)$, Swedia (1\%), dan Philipina (1\%). Sedangkan produk PT Smelting berupa katoda tembaga dijual ke domestik (dalam negeri) dan diekspor terutama ke negara-negara Asean (Gambar 5).

\section{Produksi dan Penjualan Tembaga}

PT Smelting Gresik adalah satu-satunya pabrik di Indonesia yang melakukan proses peleburan konsentrat tembaga menjadi katoda tembaga, dengan produk sampingnya berupa lumpur anoda, asam sulfat, terak tembaga, dan gipsum. Pendirian PT Smelting Gresik sendiri berawal dari kewajiban PT FI terkait tuntutan kewajiban dalam perpanjangan kontrak karyanya yang kedua. PT Smelting company merupakan sebuah konsorsium, dengan komposisi kepemilikan saham saat ini adalah Mitsubishi Materials Corporation (MMC) 60,5\%, PT Freeport 25\%, Mitsubishi Corporation 9,5\%, dan Nippon Mining and Metal Co. Ltd. 5\%. Sejak beroperasi di tahun 1998, PT Smelting telah meningkatkan kapasitas produksinya tiga kali dari 200.000 ton/tahun ke 225.000 ton/ tahun (2004), ke 270.000 ton/tahun (2006) dan ke 300.000 ton/tahun (2009). Pabrik tersebut mampu mengolah 1.000.000 ton/tahun konsentrat tembaga untuk menghasilkan 270.000 ton/tahun katoda tembaga. Bahan baku lain yang dibutuhkan adalah 150.000 ton/tahun pasir silika, 20.000 ton/tahun batukapur dan 23.000 ton/tahun batubara serta oksigen kaya berkadar sekitar 50\% (enriched oxygen).

Selama tahun 2008 - 2014, data penjualan relatif berfuktuatif dan cenderung menurun. Penjualan katoda tembaga tertinggi dicapai pada tahun 2009 sebesar 287.400 ton dan terendah pada tahun 2013 sekitar 199.643 ton, dengan komposisi penjualan antara domestik dan ekspor $57,5 \%$ ton dan domestik $42,5 \%$ ton (Tabel 2). Seperti telah disinggung di atas, tujuan ekspor katoda tembaga PT Smelting, terutama ke negara-negara Asean (67\%), yaitu ke Malaysia (31\%), Thailand (26\%) dan Vietnam (10\%), sedangkan ke negara di Asia lainnya, meliputi China (16\%), Taiwan (7\%), South Korea (6\%), dan Japan (4\%) (Gambar 6). 


\begin{tabular}{|c|c|}
\hline Tahun & $\begin{array}{c}\text { Produksikonsentrat } \\
\text { (Ton) }\end{array}$ \\
\hline 2000 & 743.697 \\
\hline 2001 & 871.389 \\
\hline 2002 & 935.505 \\
\hline 2003 & 932.106 \\
\hline 2004 & 1.007 .099 \\
\hline 2005 & 908.258 \\
\hline 2006 & 714.331 \\
\hline 2007 & 789.564 \\
\hline 2008 & 496.973 \\
\hline 2009 & 752.354 \\
\hline 2010 & 891.766 \\
\hline 2011 & 490.211 \\
\hline 2012 & 314.026 \\
\hline 2013 & 333.632 \\
\hline 2014 & 290.126 \\
\hline
\end{tabular}

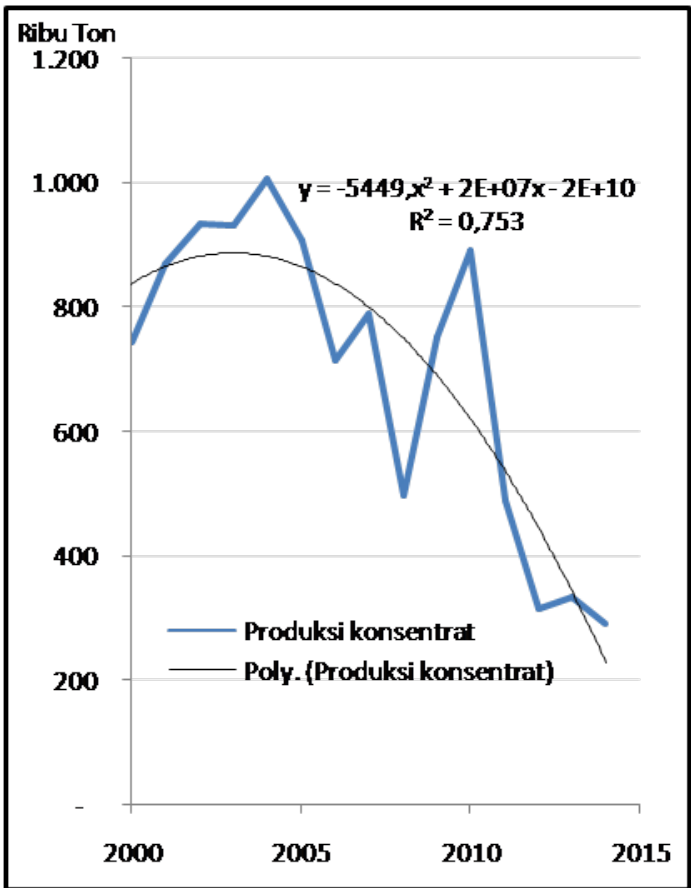

Sumber : DJMB dan PT Newmont Nusa Tenggara, 2015 (diolah kembali)

Gambar 4a. Perkembangan produksi konsentrat tembaga PT Newmont Nusa Tenggara, Tahun 2000 - 2014

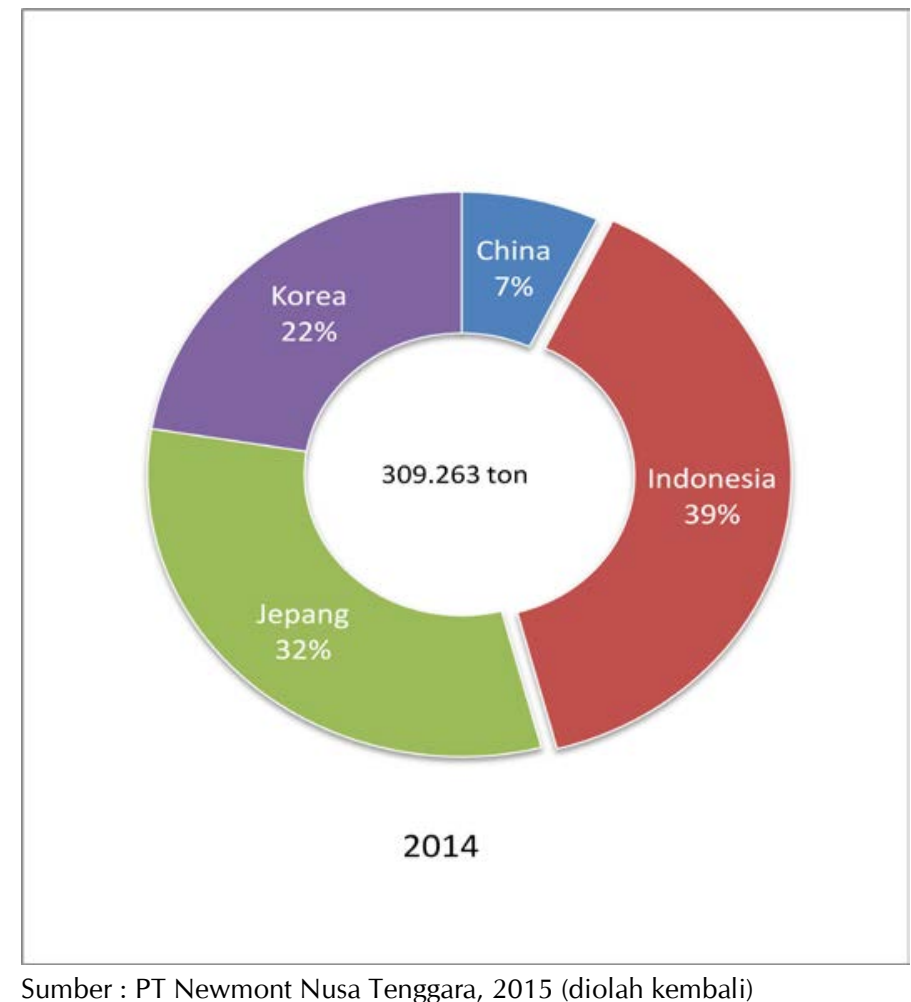

Gambar 4b. Penjualan konsentrat tembaga PT Newmont Nusa Tenggara, Tahun 2014 


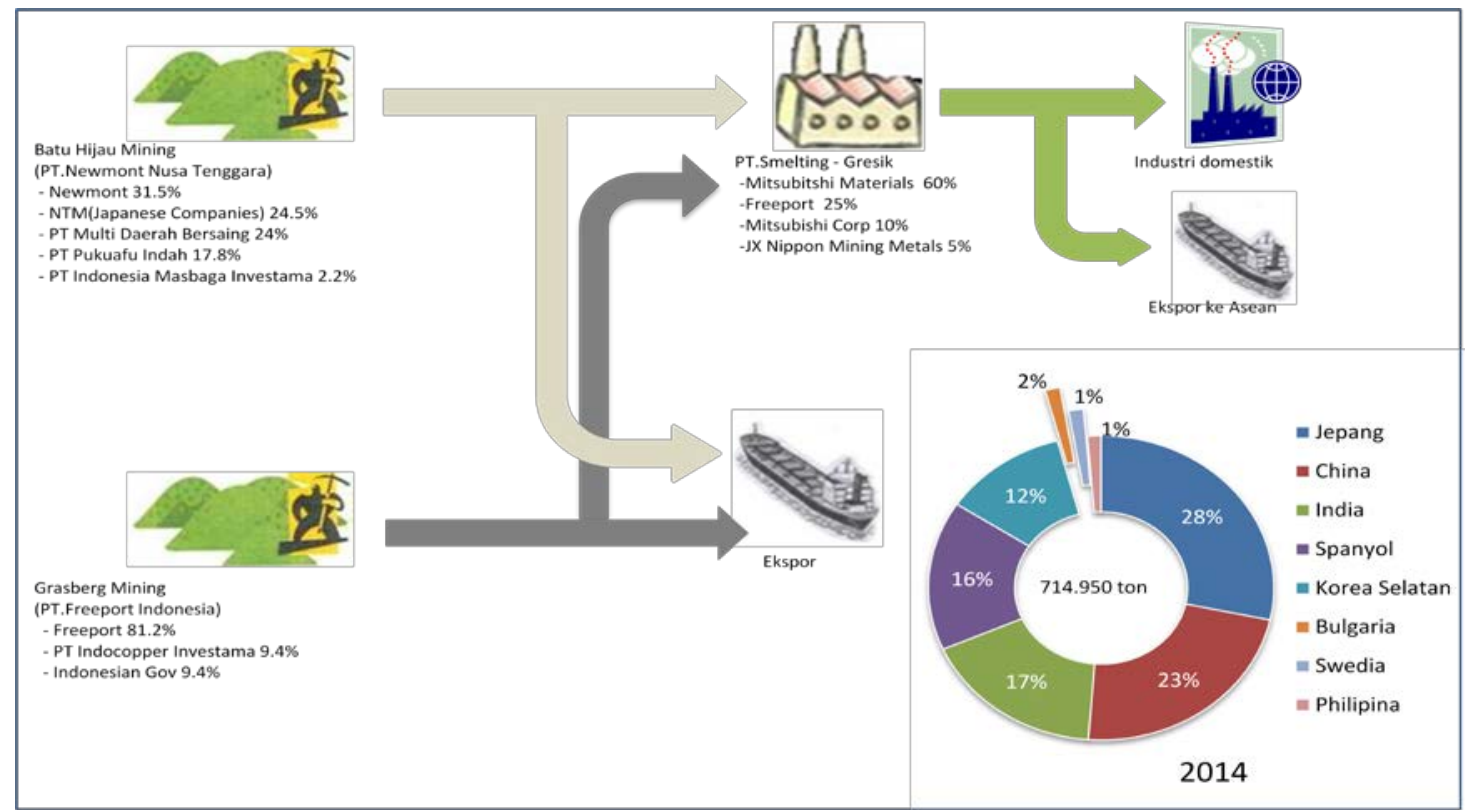

Sumber: DJPMB, 2011 dan ITC, 2015 (diolah kembali)

Gambar 5. Flow Chart produksi dan penjualan bijih dan konsentrat tembaga Indonesia

Tabel 2. Penjualan katoda tembaga PT Smelting, Tahun 2008 - 2014

\begin{tabular}{cccc}
\hline TAHUN & DOMESTIK & EKSPOR & JUMLAH \\
\hline 2008 & 111.600 & 141.400 & 253.000 \\
2009 & 94.300 & 193.100 & 287.400 \\
2010 & 117.800 & 157.400 & 275.200 \\
2011 & 134.400 & 141.600 & 257.000 \\
2012 & 110.620 & 148.380 & 259.000 \\
2013 & 82.324 & 109.998 & 192.322 \\
2014 & 89.643 & 109.995 & 199.638 \\
\hline RATA-RATA & 105.812 & 143.125 & 246.223 \\
\hline STANDAR DEVIASI & 18.089 & 28.662 & 36.369 \\
\hline
\end{tabular}

Sumber : PT Smelting, 2011 dan ITC, 2015 (diolah kembali)

\section{Perkembangan Ekspor-impor Produksi Tembaga dan Olahannya}

Apabila meninjau lebih ke hilir, dapat diketahui gambaran perkembangan ekspor produk tembaga dan olahannya dalam periode 20042013. Jumlah produk yang terdiri dari katoda tembaga, tembaga batangan, tembaga lembaran dan produk lainnya berfluktuasi dan cenderung meningkat, dengan persamaan regresi polinomial $y=-0.796 x^{2}+3.202 x-3 E^{+6}$ dan koefisien determinasi $R^{2}=0,5$. Sedangkan dari nilai jual, cenderung meningkat secara signifikan, dengan persamaan regresi linier $y=$ $489,7 x$ - 98.081 dan koefisien determinasi $R^{2}$ $=0,898$. Pada tahun 2004 tercatat 225 ribu ton dengan nilai USD 754 juta, pada tahun
2005 meningkat tajam tercatat menjadi 426 ribu ton dengan nilai USD 1.183,5 juta, kemudian pada tahun 2013 sekitar 280 ribu ton dengan nilai USD 5.845,5 juta (Gambar 7). Dari sisi impor produk olahan tersebut lebih cepat pertumbuhannya. Untuk volume impor, mengikuti persamaan regresi linier y $=25,24 x$ - 50.573 dan untuk nilai impor mengikuti persamaan regresi linier $y=228,3 x-45.773$. Tahun 2004, volume impor tercatat 46,7 ribu ton dengan nilai USD 119,1 juta, dan tahun 2013 meningkat cukup signifikan menjadi 292,7 ribu ton dengan nilai USD 2.222,9 juta (Gambar 8). Gambaran ini merupakan peluang sekaligus tantangan mengembangkan smelter tembaga di dalam negeri. 


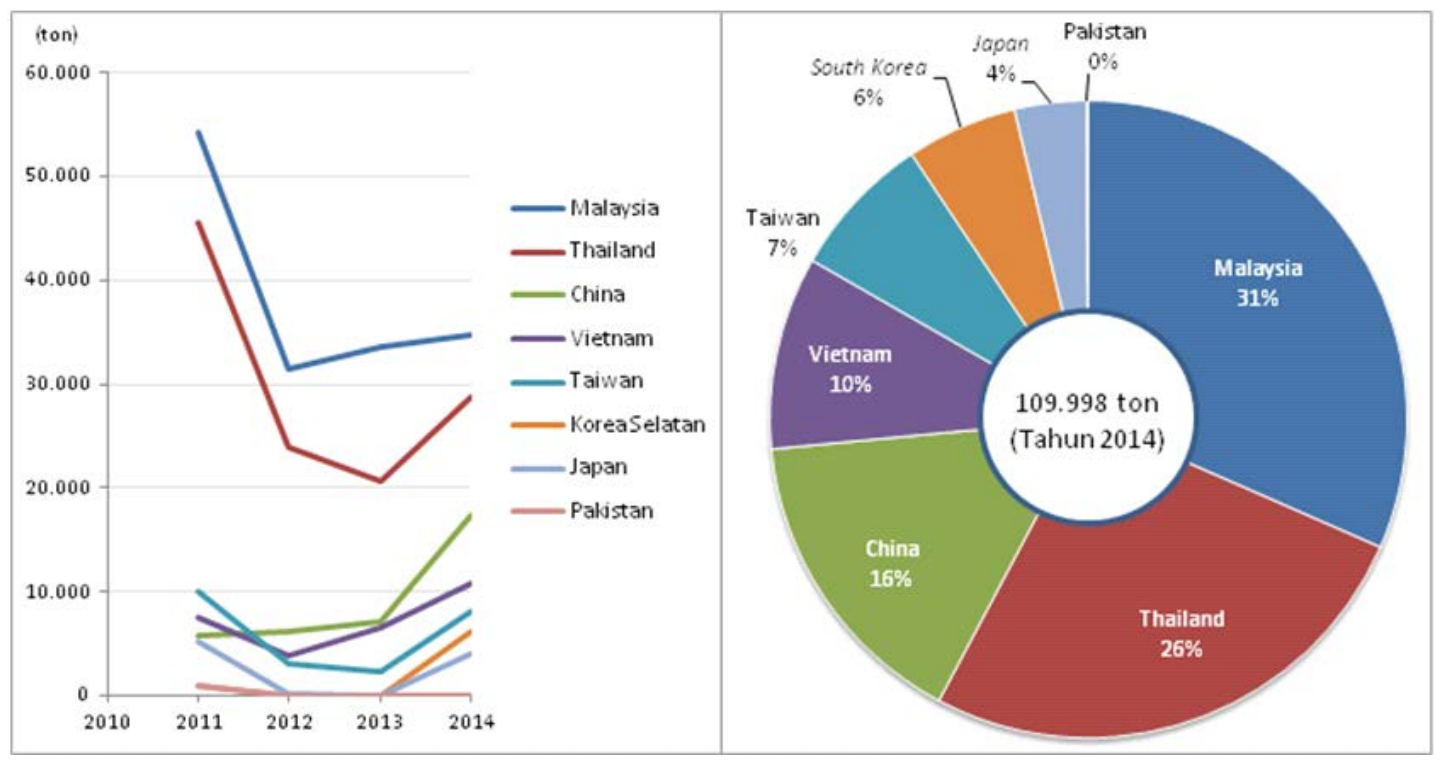

Sumber : PT Smelting, 2012 dan ITC, 2015 (diolah kembali)

Gambar 6. Ekspor katoda tembaga PT Smelting, Tahun 2011-2014

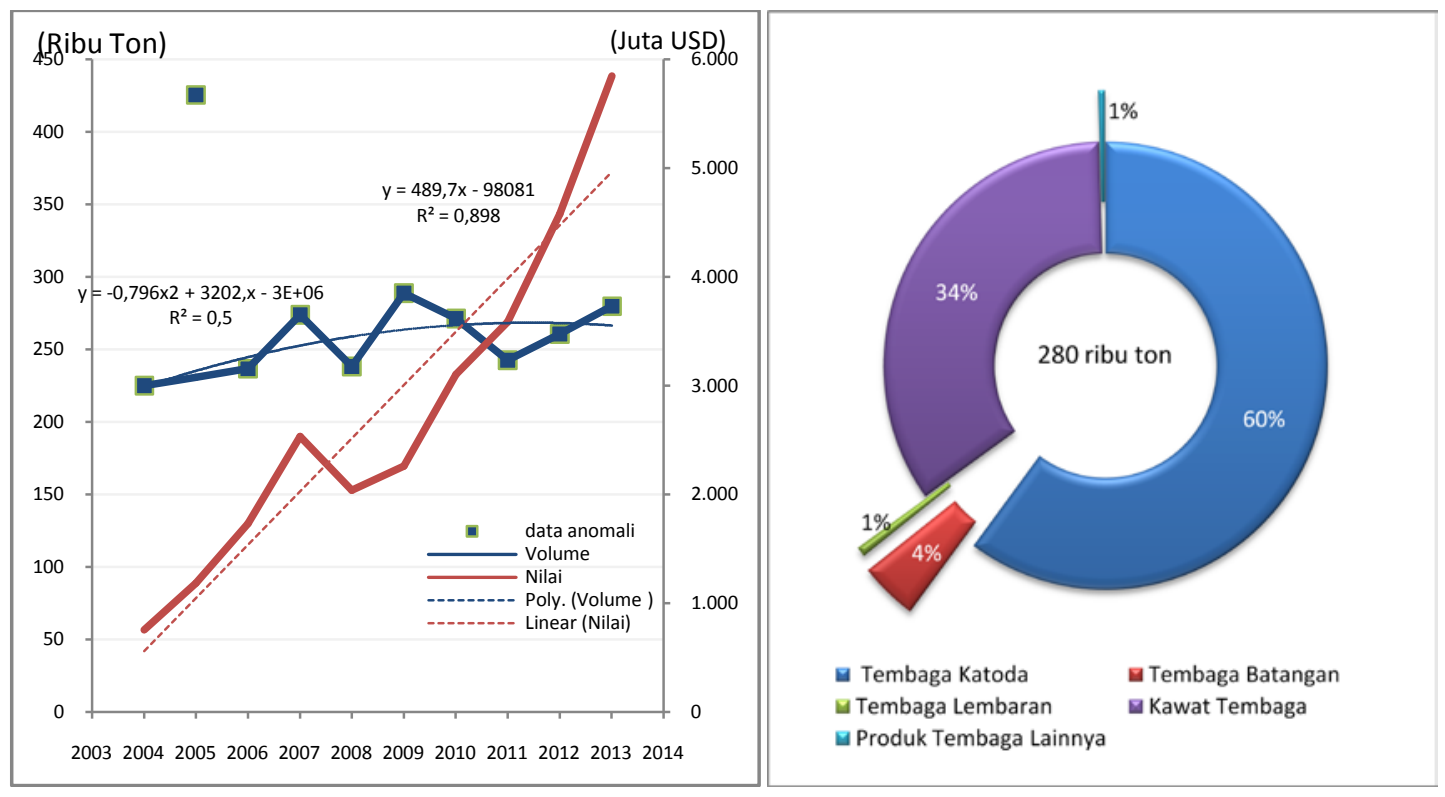

Sumber : Kementerian Perindustrian, 2013 dan BPS, 2015 (diolah kembali)

Gambar 7. Volume dan nilai ekspor tembaga dan olahannya 


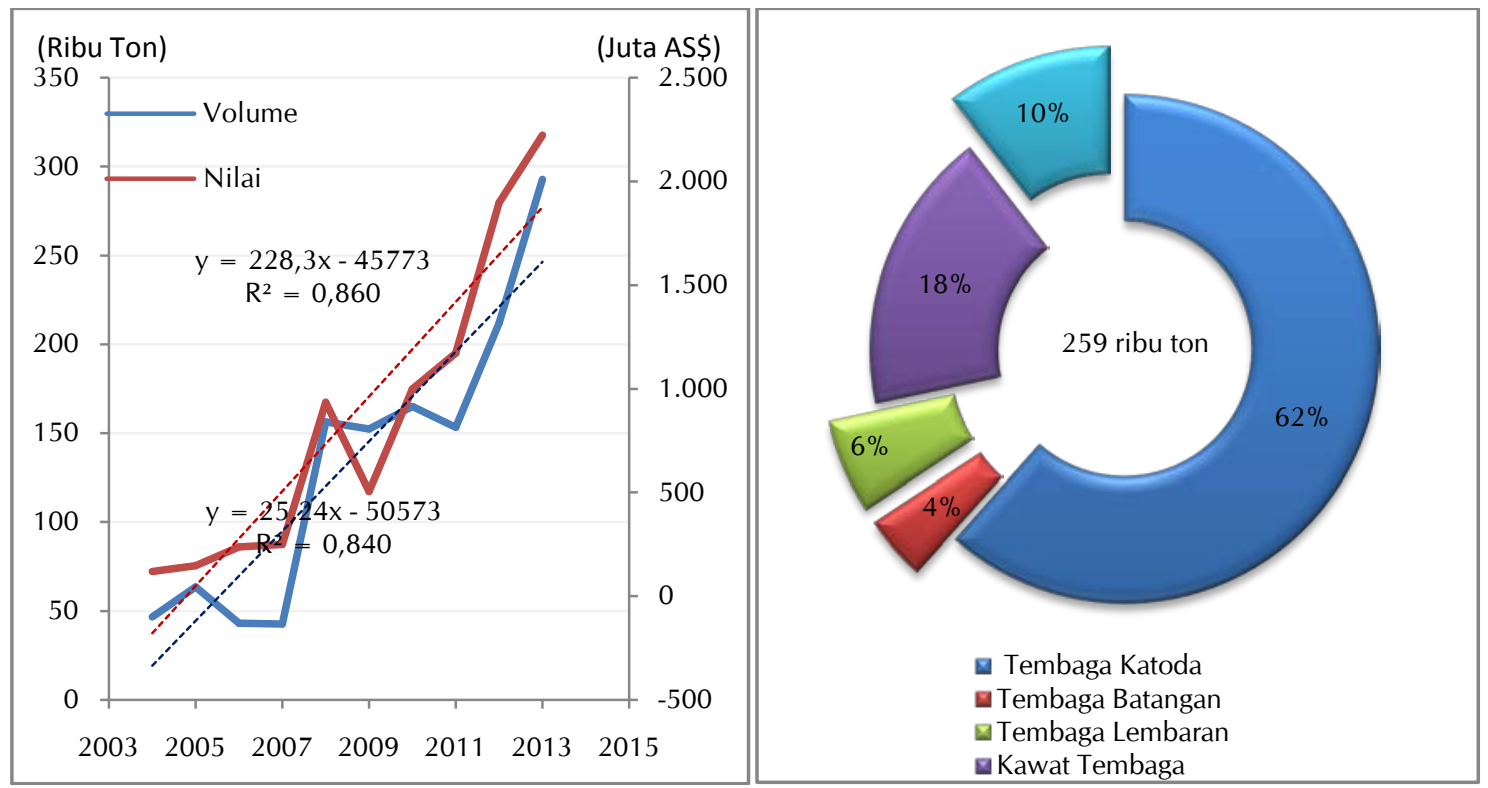

Sumber : Kementerian Perindustrian, 2013 dan BPS, 2015 (diolah kembali)

Gambar 8. Volume dan nilai impor tembaga dan olahannya

\section{Kajian Teknoekonomi Peningkatan Nilai Tambah}

Indonesia termasuk negara produsen tembaga yang didukung oleh sumberdaya dan cadangan yang besar. Gambaran keberadaan Indonesia dalam perdagangan dunia cukup menonjol dengan menempatkan PT FI dan PT NNT dalam jajaran 20 produsen tembaga skala dunia.

\section{Nilai Tambah}

Nilai tambah tembaga secara nyata meningkat dari bijih tembaga diolah menjadi konsentrat tembaga kemudian dilebur menjadi produk katoda tembaga dengan produk sampingnya (by-product) antara lain lumpur anoda yang mengandung logam-logam yang bernilai ekonomi tinggi. Nilai tambah lainnya adalah asam sulfat yang berasal dari unsur belerang yang terkandung dalam konsentrat tembaga. Produk asam sulfat sangat dibutuhkan sebagai bahan baku pembuatan senyawa amonium sulfat dan berbagai jenis super fosfat di industri pupuk. Asam sulfat ini merupakan bahan baku utama dari pabrik pupuk guna menunjang ketahanan pangan di Indonesia. Selain itu, ada produk samping lainnya, yaitu gipsum dan terak tembaga (copper slag) yang mengandung bahan substitusi untuk pabrik semen. Biasanya pabrik semen membutuhkan pasir besi untuk pengolahannya, dengan adanya copper slag maka pasir besi bisa dihemat untuk difokuskan pada pembuatan besi.

Produk mineral utama dan samping dari pengolahan konsentrat tembaga yang dihasilkan PT. Smelting adalah:

- Logam katoda tembaga berkadar $\mathrm{Cu}=$ 99,9\%; kapasitas 270.000 ton/tahun.

- Lumpur anoda, kapasitas 1.800 ton/tahun mengandung emas $(\mathrm{Au})=1,57 \%$; perak $(\mathrm{Ag})=4,52 \%$; selenium $(\mathrm{Se})=8,83 \%$; timbal $(\mathrm{Pb})=52,58 \%$; tembaga $(\mathrm{Cu})=$ $0,49 \%$; telurite $(\mathrm{Te})=0,12 \%$; bismut $(\mathrm{Bi})=$ $4,10 \%$; arsen $(\mathrm{As})=1,74 \%$ platina $(\mathrm{Pt})=$ 0,0015\%; paladium $(\mathrm{Pd})=0,0075 \%$; dan komponen logam lainnya (metal compound $=\mathrm{MC})=16,77 \%$. Lumpur anoda ini dijual ke luar negeri (Jepang).

- Asam sulfat $\left(\mathrm{H}_{2} \mathrm{SO}_{4}\right)$, kapasitas 920.000 ton/tahun yang mengandung sulfur $(\mathrm{S})$ sekitar 95\%. Produk ini dimanfaatkan oleh PT. Petrokimia untuk bahan kimia atau pupuk.

- Terak tembaga, kapasitas 655.000 ton/ tahun yang mengandung besi (Fe) antara $30-40 \%$. Terak ini belum layak dimurnikan sebagai bahan logam besi, tetapi produk ini sudah dimanfaatkan oleh pabrik semen.

- Gipsum kapasitas 31.500 ton/tahun, dimanfaatkan oleh pabrik semen. 
Dari pengolahan dan pemurnian 1 ton konsentrat tembaga dapat menghasilkan sekitar $294 \mathrm{~kg}$ katoda tembaga dengan nilai USD 2.018 dengan harga USD 6.863,4 per ton. Nilai dari produk samping berupa lumpur anoda senilai USD 1.001 dengan asumsi mengandung emas $30 \mathrm{~kg}$ dengan harga USD $35,9 / \mathrm{kg}$ dan perak $45 \mathrm{~kg}$ dengan harga USD $0,54 / \mathrm{kg}$. Selain itu, dari produk samping proses smelter terdiri dari asam sulfat sebanyak $882 \mathrm{~kg}$ senilai USD 256 dan slag $441 \mathrm{~kg}$ senilai USD 9. Nilai total produk smelting tembaga adalah USD 3.384 Sehingga nilai tambah dari produk smelting terhadap nilai bahan baku (1 ton konsentrat tembaga = USD 1.939) adalah sekitar USD 1.445 meningkat 1,74 kali lipat dari nilai bahan baku konsentrat tembaga (Gambar 9).

\section{Biaya Investasi}

Biaya investasi yang dibutuhkan untuk membangun smelter konsentrat tembaga cukup besar. Sebagai contoh PT Smelting yang dibangun di Gresik dengan kapasitas 300.000 ton katoda tembaga memerlukan biaya investasi sebesar US\$ 947 juta atau Rp 8,5 triliun dengan waktu pengembalian modal antara 10 -20 tahun.
Biaya pengolahan (Treatment Charge (T/C)) dan pemurnian (Refining Charge $(\mathrm{R} / \mathrm{C})$ ) sangat bergantung pada harga konsentrat yang sangat dipengaruhi oleh harga logam (LME) dari tembaga, emas dan perak, karena di dalam perhitungannya harga konsentrat adalah

$=$ kandungan $\mathrm{Cu} / \mathrm{Au} / \mathrm{Ag} \mathrm{x}$ recovery $(\%) \mathrm{x}$ harga $\mathrm{LME}(\mathrm{Cu} / \mathrm{Au} / \mathrm{Ag})-(\mathrm{T} / \mathrm{C}, \mathrm{R} / \mathrm{Cs})$

Perhitungan harga konsentrat tersebut disandarkan pada harga mineral logamnya di pasar internasional, sehingga dalam rumus tersebut dikurangi oleh biaya pengolahan dan pemurnian.

Sedangkan pendapatan smelter diperoleh dari:

$=\mathrm{T} / \mathrm{C}, \mathrm{R} / \mathrm{Cs}$ (utama) + Premi Katoda + Kredit Asam Sulfat dan slag

Kalau dilihat secara sepintas, maka yang memperoleh keuntungan besar adalah perusahaan tambang, karena harga jual konsentrat ke smelter ditentukan harga kandungan logamnya. Tetapi yang belum diketahui secara pasti adalah salah satu produk samping, yaitu lumpur anoda yang banyak mengandung mineral ikutan di luar emas dan perak, sedangkan produk samping lainnya sudah jelas karena langsung digunakan oleh pabrik di dalam negeri.

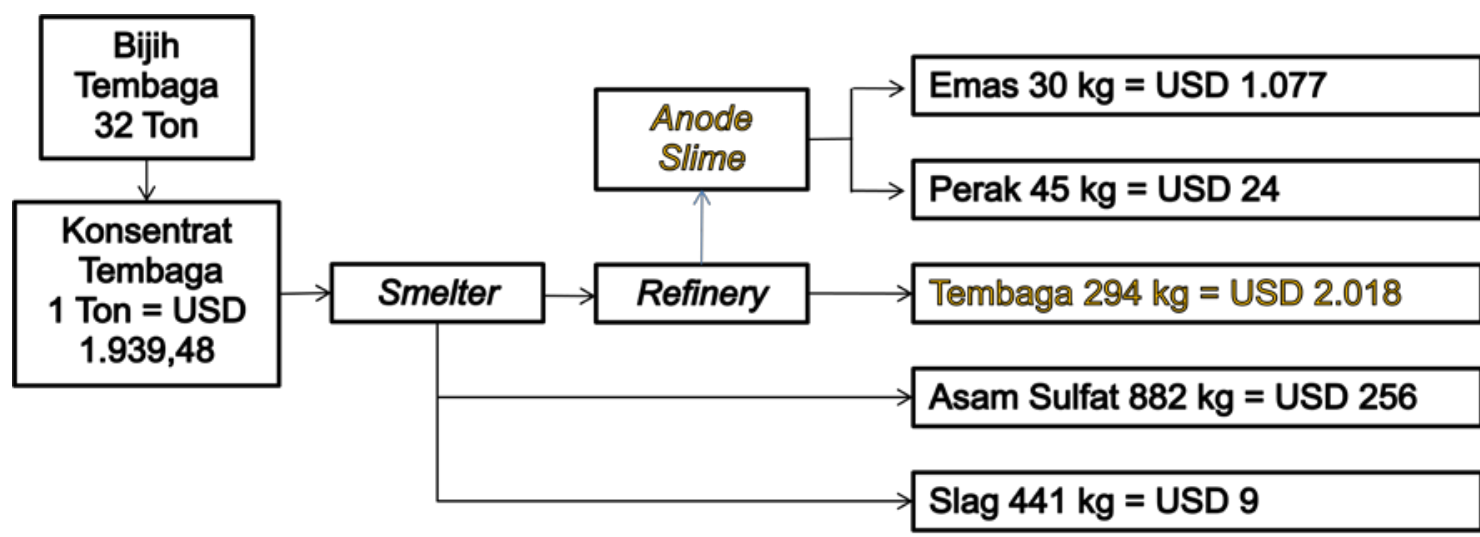

Total Nilai $=$ USD 3.384

Sumber : Hasil pengolahan (simulasi)

Gambar 9. Nilai tambah smelting 


\section{Potensi Penerimaan Negara Bukan Pajak (PNBP) dari Pengolahan dan Pemurnian Lumpur Anoda}

Berkembangnya teknologi pengolahan mineral berdampak terhadap optimalisasi perolehan mineral ikutan yang selama ini terbuang atau belum dimanfaatkan. Pengusahaan tambang tembaga di Indonesia selama ini memproduksi dalam bentuk konsentrat, dan menjualnya sebagian ke smelter domestik dan sebagian lagi diekspor. Hal tersebut sangat merugikan penerimaan negara karena belum optimalnya smelter di Indonesia, terlebih belum optimalnya pengambilan mineral ikutan yang bernilai ekonomis.

Produk konsentrat, selain mengandung logam berharga $\mathrm{Cu}, \mathrm{Au}$ dan $\mathrm{Ag}$, juga mengandung logam-logam lain termasuk logam jarang seperti Bi, Cd, Co, Mo, Sb, Se, Te. Walaupun kadarnya sangat kecil mulai dari kadar $<0,001 \%$ hingga $0,019 \%$, namun memiliki nilai ekonomi yang cukup tinggi jika diolah dan dimurnikan (Ardha dan Saleh, 2006).
Dari proses pengolahan konsentrat tembaga, selain menghasilkan logam tembaga juga menghasilkan lumpur anoda, yaitu sisa proses pengolahan yang masih mengandung unsurunsur mineral ikutan yang bernilai ekonomi tinggi. Dari hasil analisis terhadap lumpur anoda PT Smelting Gresik yang dilakukan di Puslitbang Teknologi Mineral dan Batubara (tekMIRA), diperoleh unsur-unsur mineral ikutan, komposisi dan jumlah yang akan dihasilkan (lihat Tabel 3).

Berdasarkan tarif royalti seperti dalam PP No. 9 Tahun 2012 tentang PNBP sebagai revisi PP No. 45 Tahun 2003, maka akan diperoleh tambahan penerimaan negara bukan pajak (PNBP) per tahun sebesar USD 99,296 juta, naik hampir dua kali lipat dari perhitungan royalti seperti yang berlaku sebelumnya. Potensi royalti dari mineral ikutan sekitar USD 2,331 juta. Sedangkan tambahan penerimaan perusahaan dari produk samping asam sulfat dan gipsum adalah USD 303,651 juta (lihat Tabel 4).

Tabel 3. Hasil analisis komposisi unsur mineral ikutan dalam lumpur anoda PT Smelting oleh Puslitbang tekMIRA dan PT Smelting

\begin{tabular}{lccc}
\hline \multicolumn{1}{c}{ Unsur Mineral Ikutan } & Puslitbang tekMIRA & PT Smelting & $\begin{array}{c}\text { Jumlah Mineral Yang Dapat } \\
\text { Dihasilkan }\end{array}$ \\
\hline Emas (Au) & $1,57 \%$ & $2,10 \%$ & $18-37,8$ ton/tahun \\
Perak (Ag) & $4,52 \%$ & $5.03 \%$ & $68,4-90,54$ ton/tahun \\
Bismut (Bi) & $4,10 \%$ & $4.47 \%$ & $48,6-80,46$ ton/tahun \\
Paladium (Pd) & & $185 \mathrm{ppm}$ & $135-333 \mathrm{~kg} /$ tahun \\
Platinum (Pt) & $13 \mathrm{ppm}$ & $23,4-27 \mathrm{~kg} / \mathrm{tahun}$ \\
Telurite (Te) & $0,12 \%$ & $0,33 \%$ & $2,16-5,94$ ton/tahun \\
Selenium (Se) & $8,83 \%$ & $15,76 \%$ & $117,36-283,68$ ton/tahun \\
MC (moisture contain) & & $10,10 \%$ & \\
Timbal (Pb) & $52,58 \%$ & $47,50 \%$ & $855-990$ ton/tahun \\
\hline Produk samping lainnya : & & & 382.000 ton/tahun \\
Terak Tembaga & & & 592.000 ton/tahun \\
Asam Sulfat $\left(\mathrm{H}_{2} \mathrm{SO}_{4}\right)$, & & 31.000 ton/tahun \\
Gipsum & &
\end{tabular}

Sumber : Saleh, 2012 


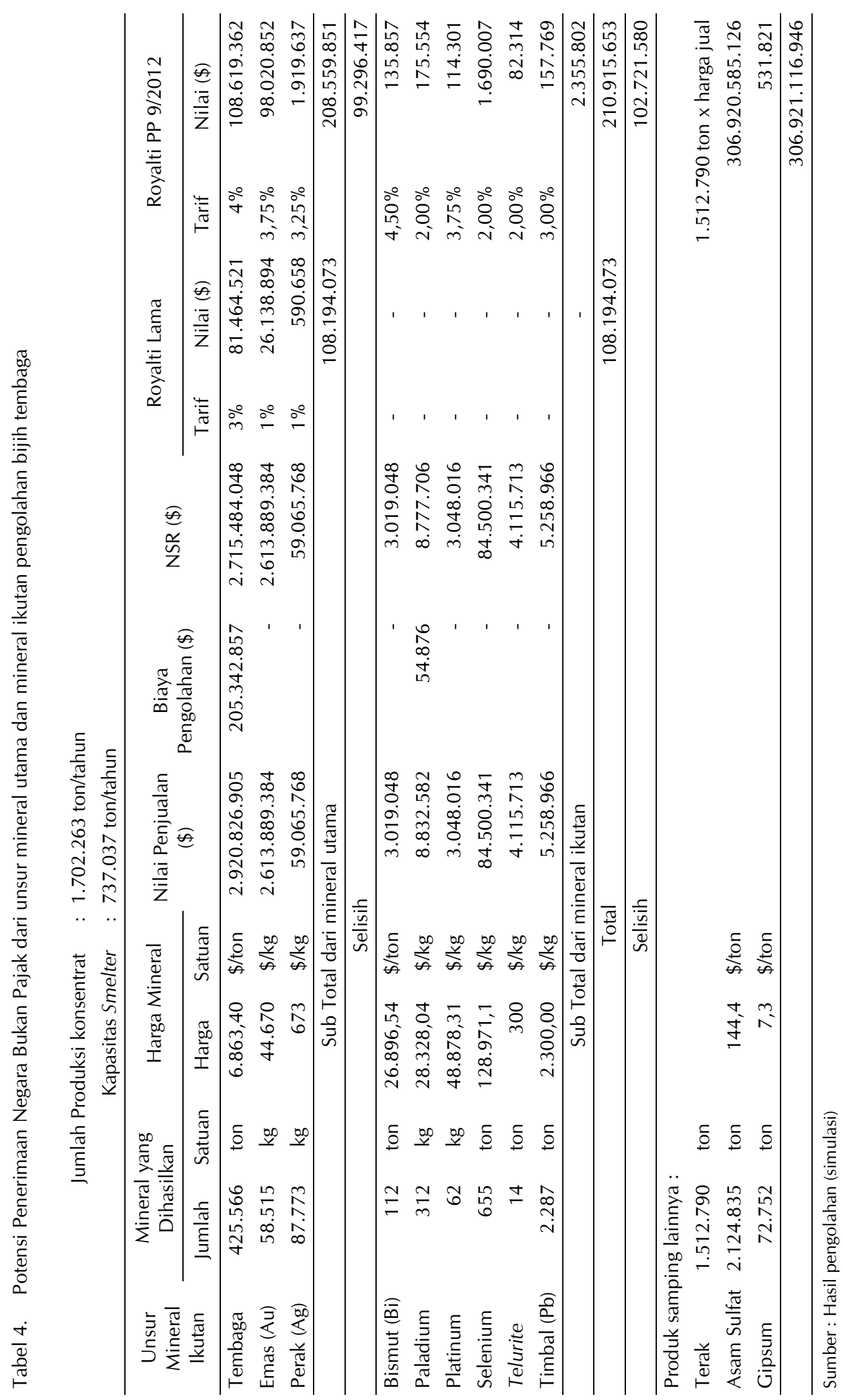




\section{Analisis Pengembangan Smelter Tembaga}

\section{Material Balance}

Hingga tahun 2013 diperkirakan sumberdaya bijih tembaga yang ada sekitar 4.925.066.645 ton dan cadangan 4.161.388.377 ton. Pada tahun 2014, PT FI dan PT NNT melakukan pengolahan bijih menjadi konsentrat tembaga sebesar 1.702.263 ton. Produk konsentrat tersebut dipasok sebagai bahan baku smelter ke PT Smelting (kapasitas 1.000.000 ton) di Gresik sebanyak 928,6 ribu ton dan ke beberapa negara di luar negeri sebanyak 773,7 ton. Di sisi lain, seperti telah diketahui bahwa diterbitkannya UU No 4 Tahun 2009 tentang pertambangan mineral dan batubara di dalamnya mengatur tentang kewajiban perusahaan untuk melakukan pengolahan dan pemurnian di dalam negeri. Dengan demikian diperlukan penambahan smelter di dalam negeri untuk mengolah konsentrat yang diekspor. Berdasarkan informasi terakhir rencana pembangunan smelter tersebut yaitu di Kabupaten Gresik berkapasitas $2 \times 1.000 .000$ ton dan di Kabupaten Mimika berkapasitas $1 \times 900.000$ ton (Gambar 10).

\section{Roadmap}

Berdasarkan data dari Ditjen Mineral dan Batubara, rencana pembangunan smelter tembaga di Indonesia adalah program pembangunan smelter di Kabupaten Gresik yang merupakan program pengembangan PT Smelting oleh PT Fl hingga tahun 2017. Roamap tersebut digambarkan secara bersama-sama dengan rencana produksi PT FI dan PT NNT seperti pada Gambar 11. Dengan masuknya rencana pembangunan smelter terseebut pada tahun 2017, hasil produksi PT FI dan PT NNT yang selama ini sebagian diekspor akan dapat diolah dan dimurnikan $100 \%$ di dalam negeri, sehingga pelarangan ekspor mulai 12 januari 2017 akan dapat dihindari setidaknya sampai 2021. Setelah tahun 2021 tersebut rencana produksi PT FI dan PT NNT mulai melebihi kapasitas smelter (sekitar 3,2 juta ton konsentrat) sehingga ada peluang untuk tambahan pembangunan smelter seperti yang direncanakan di Kabupaten Mimika, Provinsi Papua. Di sisi lain, KK PT FI akan berakhir tahun 2021. Ada persyaratan yang harus dipenuhi dalam proses perpanjangan KK tersebut, sejalan dengan perubahan paradigma. Syarat pertamanya adalah perpanjangan kontrak baru bisa dilakukan dua tahun sebelum kontraknya habis. Ini sesuai ketentuan yang diatur dalam Peraturan Pemerintah (PP) Nomor 74 Tahun 2014. PT FI baru bisa mengajukan perpanjangan kontrak pada 2019. Syarat kedua, PT FI untuk meningkatkan penggunaan barang dan jasa dalam negeri (local content) dalam kegiatan operasinya. Ketiga, terkait divestasi saham untuk dalam negeri. Keempat, meningkatkan pembayaran royalti. Pemerintah menetapkan royalti tembaga naik dari 3,5 persen menjadi 4 persen. Royalti emas dari 1 persen menjadi 3,75 persen dan perak dari 1 persen menjadi 3,25 persen. Kelima, PT FI wajib membangun smelter (Fitra, 2015).

\section{Analisis SWOT}

Untuk menentukan strategi dan tindakan yang tepat untuk mewujudkan rencana pembangunan/pengembangan smelter tembaga di dalam negeri sebagai implementasi kebijakan peningkatan nilai tambah pertambangan melalui pengolahan dan pemurnian, akan dilakukan melalui pendekatan analisis SWOT. Analisis SWOT adalah salah satu instrument perencanaan strategis yang klasik yaitu suatu alat yang berfungsi untuk mengetahui peta kekuatan (strengths), kelemahan (weaknesses), peluang (opprtunities), ancaman (threats).

Hasil inventarisasi terhadap faktor-faktor internal yaitu strenghts dan weaknesses serta hasil inventarisasi faktor-faktor eksternal opportunities dan threats berdasarkan data yang diuraikan di atas disajikan dalam Gambar 12. Langkah berikutnya adalah menentukan strategi, dengan mengkorelasikan ke empat parameter tersebut dalam suatu matrik terintegrasi seperti Gambar 13. 


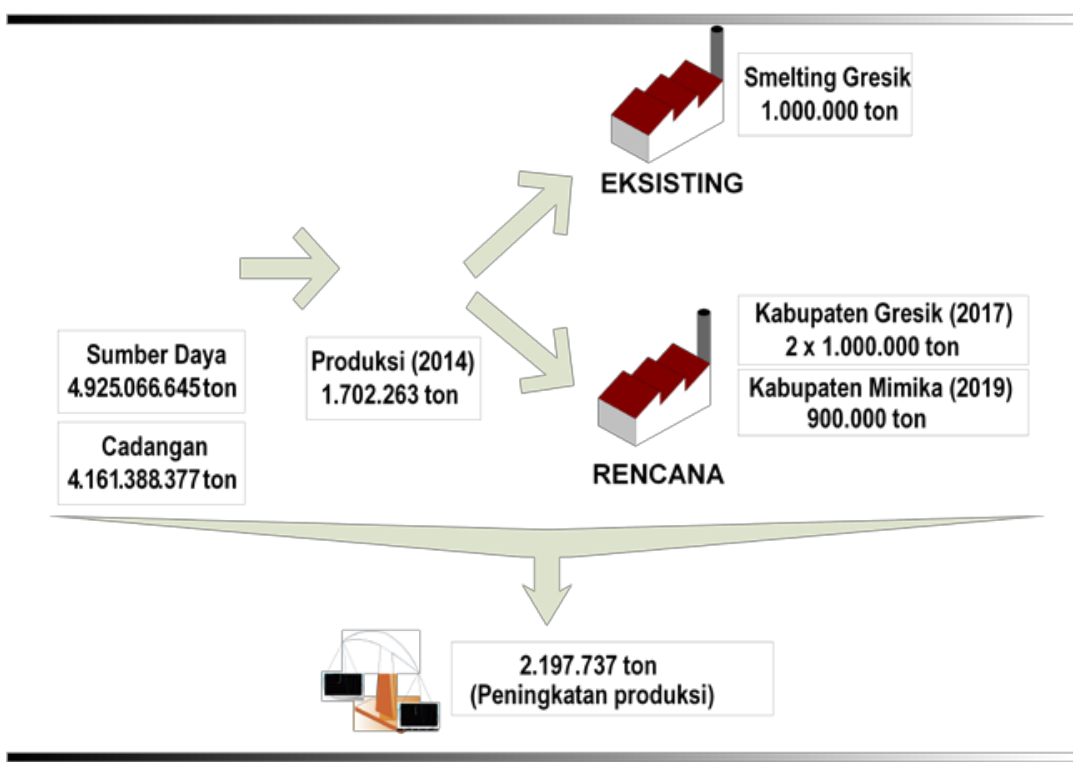

Sumber : Direktorat Jenderal Mineral dan Batubara, 2014 (diolah kembali)

Gambar 10. Material balance tembaga

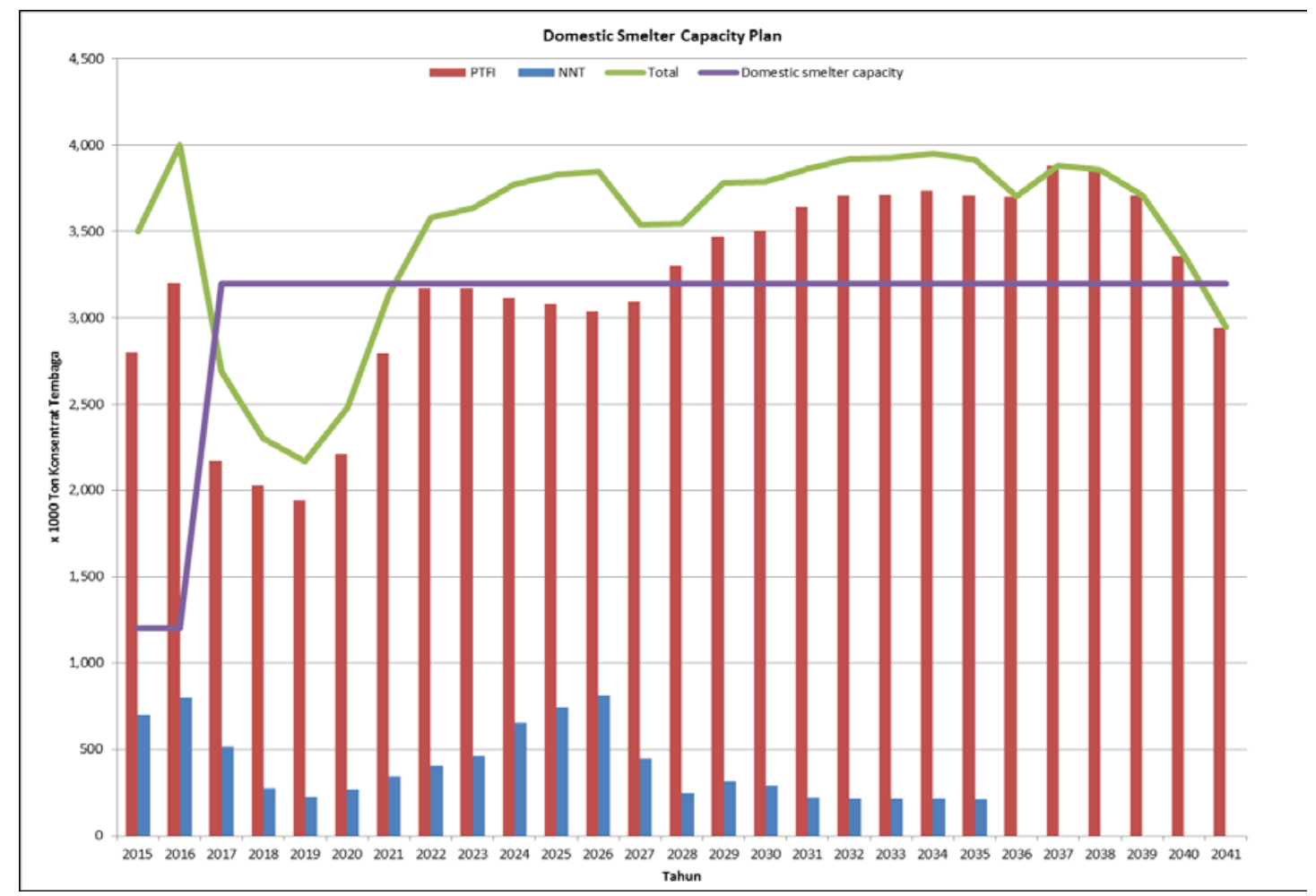

Sumber : Direktorat Jenderal Mineral dan Batubara, 2015

Gambar 11. Rencana produksi konsentrat tembaga dan kapasitas smelter tembaga di dalam negeri, Tahun 2015 - 2041 
Dari analisis SWOT tersebut dapat dikatakan bahwa untuk implementasi kebijakan nilai tambah untuk studi kasus tembaga dibutuhkan strategi sebagai berikut :

\begin{tabular}{|c|c|}
\hline $\begin{array}{l}\text { Peluang: } \\
\text { - Adanya pertumbuhan secara eksponensial } \\
\text { baik tingkat produksi tambang, refinery dan } \\
\text { tingkat penggunaan tembaga, dalam periode } \\
1960-2014 \text {. } \\
\text { - Substitusi impor produk tembaga olahan } \\
\text { cukup signifikan dan diperlukan. } \\
\text { - Penerapan teknologi smelting semakin } \\
\text { berkembang. } \\
\text { - Nilai tambah tembaga katoda } 1,74 \text { kali } \\
\text { konsentrat. } \\
\text { Meningkatkan penerimaan dari royalti dengan } \\
\text { penyesuaian tarif royalti. }\end{array}$ & $\begin{array}{l}\text { Kekuatan : } \\
\text { - Memiliki sumberdaya dan cadangan yang besar } \\
\text { (17,464 miliar ton dan 3,045 miliar ton). } \\
\text { Peranan Indonesia (PT FI dan PT NNT) di pasar } \\
\text { dunia menduduki peringkat ke } 13 \text { dalam jajaran } \\
\text { produsen tembaga skala dunia. } \\
\text { - PT Smelting-Gresik adalah satu-satunya pabrik di } \\
\text { Indonesia yang melakukan proses peleburan } \\
\text { konsentrat tembaga (sekitar } 43 \% \text { dari produksi } \\
\text { dalam negeri) menjadi katoda tembaga } \\
\text { - Telah dikuasai teknologi pengolahan konsentrat } \\
\text { dan tembaga katoda } \\
\text { PT Antam (Persero) membangunan fasilitas } \\
\text { ekstraksi logam berharga dari lumpur anoda }\end{array}$ \\
\hline & \\
\hline $\begin{array}{l}\text { Ancaman : } \\
\text { - Tumbuh industri pengolahan dan pemurnian } \\
\text { di Asia terutama di China } \\
\text { - Masuknya produk impor yang terus } \\
\text { meningkat } \\
\text { - Pemanfaatan scrape terus meningkat }\end{array}$ & $\begin{array}{l}\text { - Ketergantungan industri hilir pada bahan baku } \\
\text { impor } \\
\text { - Sebagian besar konsentrat dan lumpur anoda } \\
\text { diekspor } \\
\text { - Investasi smelting sangat besar } \\
\text { - Tidak adanya penelitian dan teknologi serta } \\
\text { pangsa pasar } \\
\text { - Insfrastuktur pendukung seperti energi listrik. } \\
\text { - Belum terintegrasinya kebijakan hulu-hilir }\end{array}$ \\
\hline
\end{tabular}

Gambar 12. Analisis SWOT pembangunan smelter tembaga

Maxi-Maxi : Strategi SO

Adanya pertumbuhan produksi tambang dan refinery secara eksponensial sebagai dampak peningkatan permintaan, di sisi lain Indonesia mempunyai sumberdaya dan cadangan yang besar (17,464 miliar ton dan 3,045 miliar ton), sehingga perlu mendorong PT FI untuk merealisasikan program pengembangan kapasitas PT Smelting Gresik dari 1 menjadi 3 juta ton tembaga. pertahun dan PT NNT untuk melakukan kerjasama dengan Smelting tersebut. Dengan demikian seluruh produk konsentrat dapat diproses hingga produk logam di dalam negeri. Sedangkan untuk rencana pembangunan smelter di Papua dengan kapasitas 900.000 ton tembaga perlu disinergiskan secara representatif dengan perusahaan yang akan membangun pengolahan bijih tembaga menjadi konsentrat tembaga, sehingga rencana tersebut secara signifikan dapat diwujudkan. Faktor penghambat yang menjadi tantangan adalah minimnya infrastruktur energi listrik maupun prasarana perhubungan, sehingga program pembangunan pembangkit listrik dengan mengembangkan potensi lokal, seperti PLTA Mamberamo di Papua perlu didukung dengan kajian yang representatif (Permana, 2010 dan Djamaluddin dkk., 2012).

\section{Mini-Maxi : Strategi WO}

Kebutuhan produk tembaga dan produk olahan (industri antara dan hilir) di dalam negeri terus meningkat, hal ini sejalan dengan produk impor yang terus meningkat (termasuk katoda tembaga), sekitar 6 kali lipat selama 9 tahun terakhir (2004-2013). Di sisi lain, PT Smelting Gresik produksinya berfluktuatif dan cenderung menurun, serta sebagian produknya malah diekspor, termasuk produk samping lumpur anoda yang kaya mineral logam jarang. Gambaran ini merupakan peluang sekaligus tantangan mengembangkan smelter tembaga, industri hilir tembaga serta mengolah lumpur anoda lebih lanjut di dalam negeri. Oleh karena perlu didukung pengembangan Smelting Gresik untuk meningkatkan produksi katoda tembaga. Demikian pula per- 
lu mendorong PT Antam (Persero) untuk terus mengembangkan pengolahan/pemurnian lumpur anoda dalam rangka optimalisasi produk samping dari smelter. Peran bank sebagai agent of development dalam hal ini untuk menyalurkan kredit kepada perusahaan industri antara (smelter) dan industri hilir (tembaga olahan) yang membutuhkan pendanaan.

\section{Maxi-Mini : Strategi ST}

Smelter dan industri hilir berbasis tembaga di Kawasan Asean (Malaysia, Thailand dan Vietnam), dan terutama di China, Taiwan dan Korea Selatan, terus berkembang. Oleh karena itu, Indonesia perlu menawarkan alternatif untuk pembangunannya di Indonesia, baik melalui PMA murni maupun pola kerjasama dengan investor lokal atau perusahaan yang sudah ada seperti PT FI, PT NNT dan PT Antam (Persero). Hal ini untuk menanggulangi impor tembaga dan olahannya. Atau investasi pada pembangunan insfrastuktur pendukung antara lain pembangkit listrik, pelabuhan, dan prasarana jalan.

\section{Mini-Mini : Strategi WT}

Karena biaya investasi pembangunan smelter sangat besar, maka pemerintah harus memberikan insentif agar program peningkatan nilai tambah ini bisa berjalan sesuai harapan (Saleh, 2012). Di samping itu diperlukan pembuatan regulasi untuk mendorong sinerginya rantai industri, perlu didukung dengan kajian Domestic Market Obligation (DMO) Hulu dan DMO Hilir, yaitu pengutamaan pemasokan kebutuhan bahan baku konsentrat untuk smelter dan pengutamaan produk pengolahan sebagai bahan baku industri hilir, yaitu regulasi yang menguta makan penjualan katoda tembaga di dalam negeri.

\begin{tabular}{|c|c|c|}
\hline & Kekuatan (S) & Kelemahan (W) \\
\hline 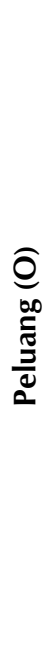 & $\begin{array}{l}\text { Maxi-Maxi : Strategi SO } \\
\text { - Mendorong PT FI dan PT NNT untuk melaku- } \\
\text { kan peleburan produk konsentrat/bijih hingga } \\
\text { produk logam dan optimalisasi produk samping; } \\
\text { - Mengembangkan kapasitas smelter di Gresik } \\
\text { atau membangun smelter di Papua, dengan } \\
\text { melakukan studi kelayakan secara kompre- } \\
\text { hensif (teknologi, finansial, dan lain-lain); } \\
\text { - Mengolah produk samping lumpur anoda } \\
\text { lebih lanjut di dalam negeri; } \\
\text { Pembangunan infrastruktur PLTU di Gresik dan } \\
\text { terutama membangunan PLTA atau PLTGU di } \\
\text { papua untuk mendukung pembangunan } \\
\text { smelter. } \\
\text { Optimalisasi penerimaan negara dengan } \\
\text { menerapkan PP } 9 \text { Tahun } 2012\end{array}$ & $\begin{array}{l}\text { Mini-Maxi : Strategi WO } \\
\text { - Mengoptimalkan substitusi impor dengan meng- } \\
\text { optimalkan produk smelting } \\
\text { - Menggalakkan litbang teknologi dan pangsa } \\
\text { pasar } \\
\text { - Mendorong pengolahan lebih lanjut untuk } \\
\text { konsentrat dan anode slime }\end{array}$ \\
\hline 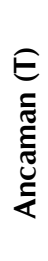 & $\begin{array}{l}\text { Maxi-Mini : Strategi ST } \\
\text { - Mengubah kompetitor menjadi mitra untuk } \\
\text { berinvestasi di DN pada smelter dan industri } \\
\text { hilir }\end{array}$ & $\begin{array}{l}\text { Mini-Mini : Strategi WT } \\
\text { - Pembuatan regulasi untuk mendorong sinergi- } \\
\text { nya rantai industri (tumbuhnya industri turunan } \\
\text { tembaga) } \\
\text { - Pengutamaan pemasokan kebutuhan industri } \\
\text { hilir dengan peraturan perundangan }\end{array}$ \\
\hline
\end{tabular}

Gambar 13. Strategi peningkatan nilai tambah tembaga

\section{KESIMPULAN DAN SARAN}

Seperti yang berlaku saat ini, penerapan UU No 4 Tahun 2009, terkait kewajiban melakukan pengolahan dan pemurnian hasil penam- bangan di dalam negeri, di samping menjual di dalam negeri, yaitu ke PT Smelting, PT FI dan PT NNT masih diizinkan untuk menjual produk konsentrat tembaga ke luar negeri (ekspor) per enam bulan, sejalan dengan kema- 
juan program (roadmap) pembangunan pabrik peleburan konsentrat tembaga hingga tahun 2017. Dari sisi jumlah produksi konsen-trat tembaga selama periode 2000-2014 baik PT FI maupun PT NNT berfluktuasi dan cenderung menurun. Kondisi pada tahun 2014, masingmasing tercatat sekitar 1,394 juta ton dan 290,126 ribu ton. Namun dari sisi penju-alan ke dalam negeri (ke PT Smelting-Gresik) secara presentase ada kecenderungan yang meningkat. Pada tahun 2014, pasokan PT FI ke PT Smelting sekitar $58,00 \%$ jauh di atas rata-rata selama periode 2000-2014 yang mencapai $26,38 \%$ pertahun. Demikian pula PT NNT, pada tahun 2014 sekitar 38,83\%, sedangkan selama lima belas tahun terakhir rata-rata sekitar $16,28 \%$ pertahun. Pengembangan mineral tembaga di dalam negeri tidak terlepas dari kondisi global dunia yang menggambarkan adanya pertumbuhan secara eksponensial, baik produksi tambang, refinery dan penggunaan tembaga sebagai dampak peningkatan permintaan. Demikian pula pasar dalam negeri cukup berkembang. Hal tersebut ditunjukkan dengan impor produk tembaga dan olahannya yang tumbuh cukup berkembang dibandingkan dengan perkembangan ekpornya. Berdasarkan hasil analisis, nilai tambah pengolahan dan pemurnian konsentrat tembaga menjadi katoda tembaga dan produk sampingnya berupa slag, asam sulfat dan lumpur anoda yang mengandung emas dan perak, adalah sekitar 1,74 kali lipat. Hal tersebut cukup untuk mendorong merealisasikan program roadmap pengembangan/pembangunan smelter di dalam negeri, yaitu program pengembangan PT Smelting oleh PT FI dan program pembangunan smelter di Papua. Pengembangan smelter di dalam negeri yang saat ini kapasitas yang ada (PT Smelting) sekitar 1,0 juta ton dapat ditingkatkan hingga kapasitas menjadi sekitar 3,0 - 3,9 juta ton per tahun. Demikian pula perlu mendorong PT Antam (Persero) untuk terus mengembangkan pengolahan/pemurnian lumpur anoda dalam rangka optimalisasi produk samping dari smelter. Di samping itu diperlukan pembuatan regulasi untuk mendorong sinerginya rantai industri, perlu didukung dengan kajian Domestic Market Obligation (DMO) Hulu dan DMO Hilir, yaitu pengutamaan pemasokan kebutuhan bahan baku konsentrat untuk smelter dan pengutamaan produk pengolahan sebagai bahan baku industri hilir, yaitu regulasi yang mengutamakan penjualan katoda tembaga di dalam negeri, menimbang industri hilirnya cukup berkembang.

\section{UCAPAN TERIMA KASIH}

Ucapan terima kasih penulis sampaikan kepada Bapak Drs. Ridwan Saleh, Drs. Triswan Suseno, dan Rochman Saefudin S.T., yang telah membantu sejak kegiatan survei lapangan hingga selesainya makalah ilmiah ini.

\section{DAFTAR PUSTAKA}

Ardha, Ngurah dan Saleh, Nuryadi, 2006. Karakteristik konsentrat PT. Freeport Indonesia dan produk PT. Smelting Co, Laporan Intern tekMIRA.

Badan Pusat Statistik, 2015. Ekspor - impor pertambangan 2012 - 2014, 2 halaman.

Direktorat Jenderal Mineral dan Batubara, 2014. Indonesia mineral and coal information 2013. 163 halaman.

Direktorat Jenderal Mineral dan Batubara, 2015. Membangun smelter tembaga nasional, Bahan Pembahasan Roadmap Pengolahan dan Pemurnian Bijih Tembaga, Jakarta 18 Februari 2015. 20 halaman.

Djamaluddin H., Thamrin M., dan Achmad A., 2012. Potensi dan prospek peningkatan nilai tambah mineral logam di Indonesia (Suatu Kajian Terhadap Upaya Konservasi Mineral), Prosiding Hasil Penelitian Fakultas Teknik, Institut Teknologi Bandung, ISBN : 978-979127255-0-6, Volume 6 : Desember 2012, halaman TG3 1-13.

Fitra, S., 2015. Perpanjangan Kontrak Freeport, Jokowi Minta 5 Syarat, Http://katadata.co.id/berita/2015/10/16/perpa njangan-kontrak-freeport-jokowi-minta-5syarat, diakses tanggal 12 Januari 2016.

International Copper Study Group (ICSG), 2015. The word copper factbook 2014, 56 halaman.

International Trade Centre (ITC), 2015. List of importing markets for a product exported by Indonesia 2011 - 2014. 4 halaman.

Islah T., 2009. Fenomena industri mineral dan prospek pendirian pengolahan dan pemurnian mineral, Buletin Sumber Daya Geologi, Vol. 4 No.3, December 2009. 
Kementerian Perindustrian, 2013. Hilirisasi mineral meningkatkan potensi industri mineral, Media Industri No 04 2013. 66 halaman.

Permana D., 2010. Tantangan dalam peningkatan nilai tambah mineral dan batubara, Jurnal Teknologi Mineral \& Batubara, Volume 8/No. 4-Desember 2010, halaman 4 - 12.

Presiden Republik Indonesia, 2009. UndangUndang Republik Indonesia Nomor 4 Tahun 2009 tentang Pertambangan Mineral dan Batubara.

Presiden Republik Indonesia, 2012. Peraturan Pemerintah Republik Indonesia Nomor 9 Tahun 2012 tentang Jenis dan Tarif Penerimaan Negara Bukan Pajak Yang Berlaku Pada Kementerian Energi Dan Sumber Daya Mineral.

PT Freeport Indonesia (PT FI), 2015. Data dukung untuk kajian local content dan manfaat keberadaan PTFI di Papua. 56 halaman.
PT Newmont Nusa Tenggara (PT NNT), 2015. Produksi dan penjualan konsentrat tembaga. 2 halaman.

PT Smelting, 2012. Peleburan tembaga \& lumpur anoda. 20 halaman.

Pusat Sumber Daya Geologi, 2013. Data sumber daya dan cadangan tembaga tahun 2012. 5 halaman.

Saleh, R., 2012. Potensi peningkatan nilai tambah dari logam ikutan hasil pemurnian tembaga, Jurnal Teknologi Minertal dan Batubara, Volume 8, Nomor 1, Januari 2012, halaman $17-27$.

Yunianto B., 2014. Analisis dampak penerapan kebijakan nilai tambah mineral indonesia terhadap ekspor dan tenaga kerja, Jurnal Teknologi Minertal dan Batubara, Volume 10, Nomor 3, September 2014, halaman 127 $-141$. 